\title{
Indigenous Water Ontologies, Hydro-Development and the Human/More-Than-Human Right to Water: A Call for Critical Engagement with Plurilegal Water Realities
}

\author{
Lieselotte Viaene (ID
}

check for updates

Citation: Viaene, L. Indigenous Water Ontologies, HydroDevelopment and the Human/ More-Than-Human Right to Water: A Call for Critical Engagement with Plurilegal Water Realities. Water 2021, 13, 1660. https://doi.org/10.3390/ w13121660

Academic Editors: Bruce M. Wilson, Malcolm Langford and Rebecca Schiel

Received: 2 April 2021

Accepted: 3 June 2021

Published: 14 June 2021

Publisher's Note: MDPI stays neutral with regard to jurisdictional claims in published maps and institutional affiliations.

Copyright: (C) 2021 by the author. Licensee MDPI, Basel, Switzerland. This article is an open access article distributed under the terms and conditions of the Creative Commons Attribution (CC BY) license (https:// creativecommons.org/licenses/by/ $4.0 /)$.
Department of Social Sciences, University Carlos III de Madrid, 28903 Madrid, Spain; lviaene@clio.uc3m.es

\begin{abstract}
Water conflicts across the world are bringing to the fore fundamental challenges to the anthropocentric boundaries of the human rights paradigm. Engaging with the multi-layered legal ethnographic setting of the Xalalá dam project in Maya Q'eqchi' territory in Guatemala, I will critically and empirically unpack not only the anthropocentric boundaries of the hegemonic human rights paradigm, but also the ontological differences between indigenous and Euro-Western legal conceptualizations of human-water-life. I argue that it is necessary to pave the way for urgent rethinking of the human right to water and, more broadly, human rights beyond the modern divide of nature-culture. International law and human rights scholars should therefore not be afraid of plurilegal water realities and should start engaging with these ontologically different concepts and practices. Embarking on a bottom-up co-theorizing about human and beyond-the-human water rights will be imperative to avoid recolonization of indigenous knowledges-ontologies by non-indigenous scholarships and public policy.
\end{abstract}

Keywords: legal ethnography; more-than-human; rivers; Guatemala; indigenous Maya Q'eqchi'

"For those who do not speak our languages, we are invisible."

(Humberto Ak'abal, Maya Kakchiquel Poet, Guatemala)

\section{Introduction}

"Xmux'bal yuam nimla ha" or "the life of the river will be desecrated/violated". This phrase surfaced many times during the conversations, meetings and focus groups in May 2014 with Maya Q'eqchi' women, men and elders about the impact of the planned Xalalá hydroelectric dam on the Chixoy river, which the Guatemalan government was pushing forward. That same month, the then president and ex-general Otto Pérez Molina publicly defended this hydropower project, which would become the second largest dam in the country, as a "priority and of great need for the nation" [1] because it would be crucial for Guatemala's transformation of its energy matrix towards renewable energy. However, for the dam-threatened indigenous communities, the construction of this hydroelectric dam would create only destruction and loss, as "they will cut the veins of the earth" and "if they cut the river, it will dry up. It's as if the blood in our body dries up, it's similar to what happens to the water." So, with this dam, "loq'laj nimla ha Chixoy will suffer, will cry", was repeatedly said by the Q'eqchi.

While much of the academic debate about extractive hydro development projects and their socio-political and environmental impacts has taken place in the fields of political ecology, water justice and water governance, in this article, I develop a critical legal anthropological approach to the analysis of human rights at risk and call for recognition of and a critical engagement with plurilegal water realities. It is internationally recognized that the construction of hydropower dams often seriously and irreversibly violates the human rights of the various social groups involved, in particular women and indigenous peoples, who may be disproportionately affected [2]. In 2000, the World Commission 
on Dams, a global multi-stakeholder body endorsed by the World Bank and the World Conservation Union, established a comprehensive framework for the dam-building sector, which promotes the application of a "human rights approach". This approach should provide "a more effective framework for the integration of economic, social and environmental dimensions in options assessment, planning and project cycles" [2] (p. 206) and includes both recognition and assessment of rights put at risk during the management of hydropower projects across the design, decision-making and implementation phases [2] (pp. 206-210). In a guide to a rights-based approach to dam-building, the international NGO Rivers International identified more than 20 civil, political, social, labor and cultural rights, and also specific human rights such as those of women, children and indigenous peoples, that could be threatened by these infrastructural constructions [3]. These include human rights such as self-determination, the right to life, equality and non-discrimination, freedom of expression, the right to decent housing and children's rights.

This article focuses on one of the key human rights put at risk by the construction of hydroelectric dams - the human right to water and sanitation - which "fundamentally changes the right to access and use water for people affected by dams, by flooding, draining, and / or changing the flow of the river on which they depend" [3] (p. 9). Ten years ago, the United Nations (UN) General Assembly explicitly recognized the right to water and sanitation as a human right essential to the realization of all human rights and a right that the UN Human Rights Council confirmed is legally binding upon states to respect, protect and fulfil [4]. This formally recognized the Committee on Economic, Social and Cultural Rights' definition of the right to water as "the right of everyone to sufficient, safe, acceptable and physically accessible and affordable water for personal and domestic uses", established in its General Comment No 15 of 2002 and derived from the right to an adequate standard of living (article 11) of the International Covenant on Economic, Social and Cultural Rights.

Political ecologists have pointed out that the value of water is defined in economic terms and that the access to it protected by this human right is predominantly "understood and seen as organized through market mechanisms and the power of money, irrespective of social, human or ecological need" [5]. Though, in line with the insightful reflection of legal anthropologist Sally Engle Merry that "while anthropologists like to destabilize existing categories, like gender and rights ... lawyers want to clarify categories, define things and to be sure you know what you are talking about" [6], this article focuses legal ethnographic attention on the human right to water within the context of the human rights risk assessment of extractive industries in indigenous territories. I argue that the human rights field should not take for granted what water is. Against the background of the interlocking challenges that global water conflicts, climate emergency, species extinctions, ecological devastation and also pandemics pose to the human species, I argue that it is necessary to destabilize the dominant Euro-Western legal concept of water as a commodity, a natural resource to be extracted and used for human consumption. There is an urgent need to reconceptualize human rights with ontologically different ways of understanding and relating to human-water-life through bottom-up co-theorizing in order to pave the way for human rights beyond the human.

This article is grounded in and draws on my long-term collaborative legal ethnographic work with Maya Q'eqchi' communities living in the north-west of the Guatemalan Alta Verapaz department in academic and policy research projects, spanning almost 20 years, about the state-led violence and genocide during the 1970s and 1980s, transitional justice processes and the impact of hydroelectric dams. Over the course of these interrelated research projects, new and ever deeper theoretical and methodological research questions surfaced. At the same time, during my diverse human rights practitioner's experiences, amongst others at the UN Office of the High Commissioner for Human Rights (OHCHR) in Ecuador, (from 2010 to 2013 I was responsible for the areas of indigenous and afro-descendants' collective rights and transitional justice). I was confronted with the internal limits of the hegemonic human rights discourse and norms. My different 
personal paradigm shifts that unfolded during these years are beyond the scope of this article, but the process of understanding the complex Maya Q'eqchi' ontological-legal concepts of human-water-life relations led me-a Global North-trained and -based white legal anthropologist-to realize that the "real-world law is intrinsically plural" [7]. In 2002, during my first ethnographic encounter with Q'eqchi' survivors of the State-led genocide, an old woman told me: "The Tzuultaq'a is God because yoyo, it lives". As a young Belgian student of anthropology, I thought I was being told about a "belief", one more myth among the many held by Mesoamerican indigenous peoples. Over the years of this empirical engagement, however, I learned from the Q'eqchi' that the Tzuultaq'a is, following Peruvian anthropologist Marisol de la Cadena, "not only" [8] a belief in the Euro-Western significance of the word. It is much more: Tzuultaq'a, which literally means Mountain-Valley, has an ontological status framing Maya Q'eqchi' identity, being and relationship with their natural environment or what is increasingly conceptualized as the "no-human", "more-than-human" or "other-than-human" in different fields of social science [9-11]. In this article, I use the phrase "human-water-life" when referring to the Maya Q'eqchi' way of conceptualizing water for, as will be discussed in depth in Section 3, this captures the meaning of water's interdependent relationship with human beings, in which its well-being is not centralized to the human.

Recently, some critical legal theory scholars within the field of international law have been embarking on a critical examination of the fact that "the human subject stands at the center of the juridical order as its only and true agent and beneficiary" [12]. Moreover, a growing number of scholars and practitioners of international environmental law have recently begun to discuss the decentering of this anthropocentric dogma, shifting towards an eco-centric and ecosystem approach [13]. However, even though these fields of international law, human rights and environment are increasingly engaging with historically marginalized and excluded epistemologies, such as indigenous legal concepts, I argue that they do not sufficiently engage with the ontological questions these water pluralities bring to the fore.

In fact, indigenous human-water-life relationships, such as those discussed regarding Maya Q'eqchi', unveil competing political and legal water realities that interrogate key modern assumptions, which have organized dominant understandings of the modern world and everyday power relations affecting law, natural resources, development and territory. Indeed, it should be recognized that "reality is historically, culturally and materially located" [14] and therefore "the world is not simply epistemologically complex. It is ontologically complex too" [15]. In line with Canadian Métís anthropologist Zoe Todd, I therefore call on the human rights field to recognize these indigenous human-water-life relationships in the midst of extractive development projects as "concrete sites of political and legal exchange" [16], which should inform a critical narrative that de-anthropocentralizes and decolonizes the core dogma of human rights.

This article is organized as follows: First, I describe the sociopolitical and economic research setting of the Guatemalan hydropower Xalalá dam project, in which collaborative legal ethnographic work was carried out over the course of different policy-related and academic research projects. I then interweave the complex ethnographic accounts of Q'eqchi' human-water-life relationships, which suggest that water goes beyond the dominant conceptualization as water as a human right and a natural resource. I end by discussing several underexplored political and scientific areas of contestation that need to be addressed in order to engage critically with plurilegal water ontologies in international law and human rights scholarship.

\section{Situating the Research: Collaborative Legal Ethnography of the Guatemalan Xalalá Dam Project}

"We don't want more problems like in the 1980s. No longer with firearms, now they are looking for other ways to terminate us." 
The Xalalá dam project is one of Guatemala's historical and controversial dam projects. Since the early 1970s, this hydropower project has hung like a sword of Damocles above almost a hundred of Guatemalan indigenous Q'eqchi' Mayan communities living alongside the Chixoy river, the natural frontier between the departments of Alta Verapaz and El Quiché. In this section, I set the sociopolitical and economic research scene in which the long-term collaborative legal anthropological research has unfolded, outlining the human rights at risk from the construction of this hydropower project.

\subsection{Some Background to Xalala's Hydropower Socio-Political-Economic Minefield}

Two decades earlier, in 1951, the country's first National Economic Development Plan stated that hydropower was "the key means to power a national export-oriented economy" [17], since the proposed economic transformation included creating a highway system, expanding communications and power lines, exploiting timber and mineral and oil extraction, which required a reliable and accessible energy source. In 1974, after a five-year study financed with loans from the World Bank and the Inter-American Development Bank, the National Electrification Institute (INDE), an independent public entity created in the late 1950s and run by former members of the armed forces, published its first National Energy Master Plan. This identified the Xalalá dam project as one of the top four priority construction sites amongst 22 hydropower projects nationwide [18]. The plan was to develop the Xalalá dam, with an energy potential of 181 megawatts (MW), parallel to the construction of the Chixoy dam, located a few kilometers upstream. While a specific hydroelectric feasibility study and an engineering and site-specific construction plan were developed, the Xalalá project was suspended in the early 1980s due to the emergence of the internal armed conflict and to changes in the vision of the multilateral banks.

The first on this list of four priority sites was the Chixoy dam, which, started in 1976, was enabled by state-sponsored violence against the indigenous communities living at the construction site and along the riverbanks [17]. By 1983, when the dam was completed, the Guatemalan army had destroyed and massacred ten indigenous communities settled along the river. In the community of Río Negro, 444 of its 791 indigenous Achi community members were killed and the survivors of the massacres in the other neighboring villages, around 3500 indigenous people, were forcibly displaced and resettled in various communities, where they were subjected to threats, torture, forced labor and other human rights violations [19]. The World Bank and the Inter-American Development Bank provided the Guatemalan State with the loans needed to build this dam, the biggest constructed in Guatemala to date. The massacre survivors were able to bring the destructive impact of this dam to international forums such as the above-mentioned World Dam Commission, which drew attention in its final report to the gross human rights violations associated with internationally financed hydropower development [2]. In 2012, the Inter-American Court issued its ruling on the Rio Negro massacres vs. the Government of Guatemala, which linked the construction of the Chixoy hydroelectric plant with the massacres committed against the Maya Achí community of Río Negro. The Court stated that together with their displacement and resettlement to another community, the dam made it impossible for them to return to their territory and "led to the destruction of their social structure, family disintegration and the loss of their cultural and traditional practices" [19].

In 2004, the Xalalá project returned to Guatemala's energy and economic agenda as part of INDE's new Strategic Plan for Hydroelectric Projects. Since then, INDE and successive neoliberal governments have undertaken a range of actions, such as updating the feasibility and engineering studies and elaborating socio-economic evaluations, in order to promote its construction [20]. This dam project is located in Maya Q'eqchi territory and overlaps with the Petén-Veracruz eco-geographic region, which, when joined with Mexico, is considered the most extensive tropical formation in Mesoamerica [21,22].

As the Guatemalan State has ratified the International Labor Organization's (ILO) Indigenous and Tribal Peoples Convention 169, the indigenous dam-threatened communities should be consulted with the aim of obtaining their free, prior and informed consent 
(FPIC) regarding legal and administrative measures that directly affect their individual and collective human rights (see articles 6.1 and 16.2 of the [23] and articles. 15.2, 19, 32.2; of the [24]). Should these measures imply internal displacement, free and informed consent is required according to international human rights law. Moreover, according to these standards, consultations must be channels through which indigenous peoples themselves can actively contribute to the prior assessment of potential impacts of the planned activity, including whether and to what extent their individual and collective human rights may be affected [25]. It is beyond the scope of this article to discuss the ongoing political and legal debates about the lack of implementation of the collective indigenous right to free, prior and informed consultation and consent; however, the local communities alongside the river increasingly organized themselves against this hydroelectric plant project due to the lack of a state-led consultation process. In 2007, a first Community Good Faith Consultation (consulta popular) was organized in which 90 percent of the more than 21,000 inhabitants of the Ixcán municipality voted against the dam project and other extractive projects in their region. Three years later, in the neighboring municipality of Uspantán, another Community Consultation took place in which, again, the overwhelming majority of the Q'eqchi' inhabitants rejected the mining and hydroelectric projects under discussion, including Xalalá [26].

After the first successful Community Consultation, a grassroots coalition of 37 directly dam-threatened indigenous communities from the three affected municipalities organized itself into the Association of Communities for Development and in Defense of Territory and Natural Resources (ACODET) [27]. With the support of local and international nongovernmental organizations, such as Asociación Puente de Paz and the Network in Solidarity with the People of Guatemala (NISGUA), ACODET started to document the potential economic, social, cultural, and environmental impacts of the construction of the dam. One of the outputs of this collective collaborative work was the creation of a map (Figure 1),

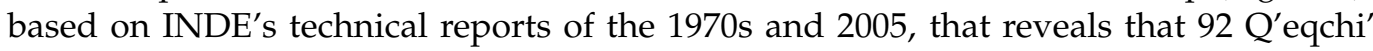
communities, or almost 30,000 people, would be affected, of which 48 communities would be directly displaced from their lands.

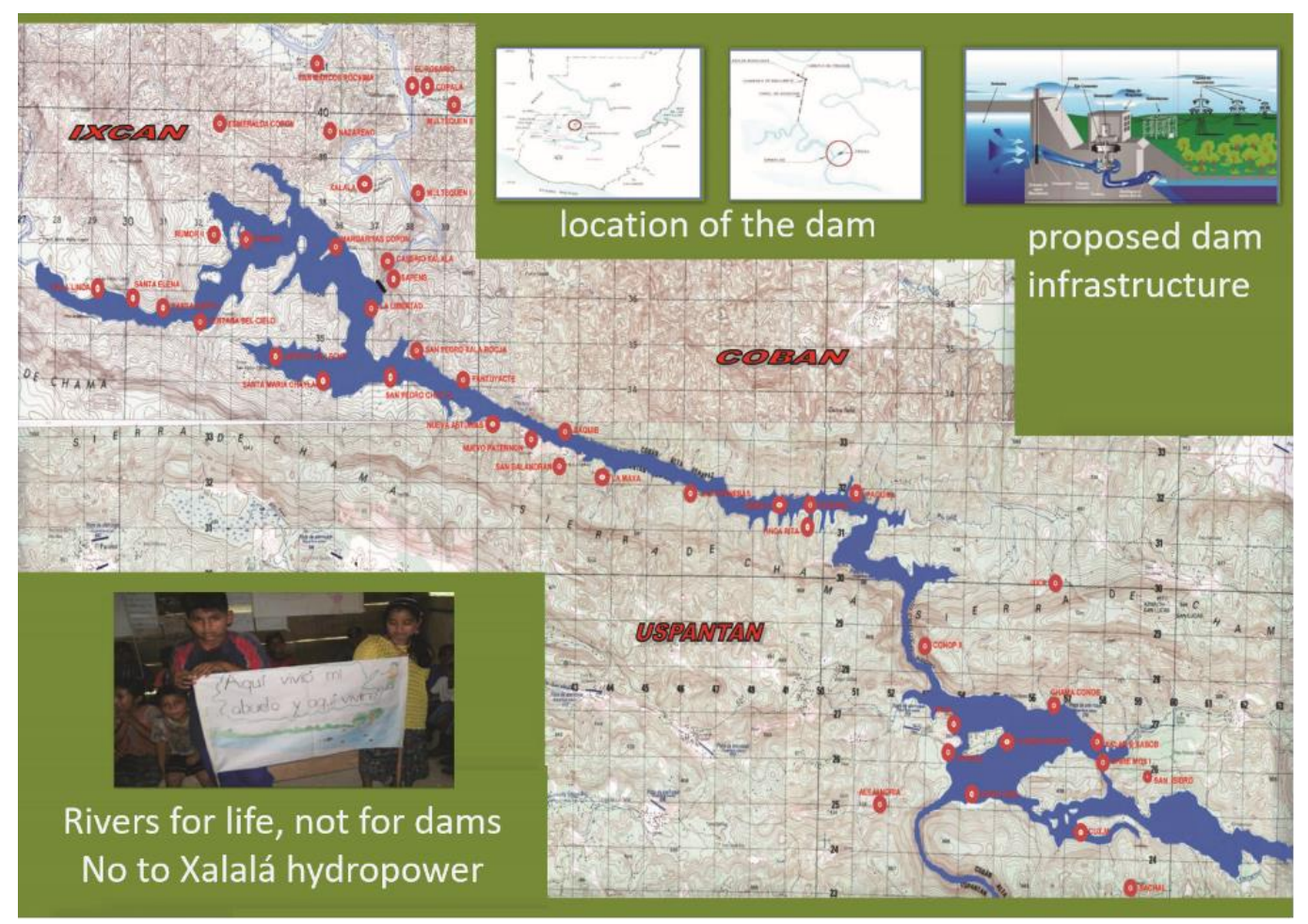

Figure 1. Map of impact of Xalalá dam project elaborated by ACODET and Asociación Puente de Paz [22] (original in Spanish, translated by author). 
These consultations forced the then administration of Álvaro Colom to step back and put the project on hold, but the following government of Otto Peréz Molina (2012-2015) ignored this collective indigenous resistance and in 2013 reopened an international bidding process for the feasibility studies and the construction of the Xalala dam [20]. At the same time, ACODET, with the support of indigenous lawyers, started to take legal action against the bidding process and publicly denounced INDE. Despite the protest and legal action, in November 2013, INDE signed a contract with a Brazilian company to conduct a geological, geotechnical, seismic and geophysical feasibility study of the Xalalá hydroelectric project. In parallel, INDE developed a new vision for the project's management characterized by a socalled comprehensive management model, based on a previously elaborated demographic and socio-economic diagnosis of the communities located in the project's area of influence.

\subsection{A Need for a Human Rights Assessment from Indigenous Perspectives}

Within the context of this hydropower extractive socio-political and economic "minefield" [28], towards the end of 2013, I was asked by the Municipality of Herent in Belgium, which had since 2000 an "international city-to-city link" (A city-to-city link is an international partnership between a Flemish municipality and a municipality from the Global South financed by the Government of Flanders (Belgium). The mutual objective is to strengthen local administrative powers through capacity building processes. To date, 35 Flemish municipalities have twinned with a municipality in Africa, Asia or Latin America. In the case of the Municipality of Herent, their original city-to-city link was with the municipality of Cobán, however in order to support the strengthening the indigenous authorities' structures, Herent municipality decided to collaborate directly with the indigenous micro-regions.) (hermanamiento) with the micro-regions Nimlaha'kok and Nimlasachal located in the Cobán municipality, to conduct a human rights assessment of the potential risk to and violations of the collective and individual human rights of the dam-threatened Maya Q'eqchi' communities resulting from the Xalala dam (the research also had the institutional support of the Centre for Human Rights of Ghent University (Belgium), where at that time I was associate post-doctoral researcher.). Previously, during my PhD research (2006-2010) on local post-conflict and transitional justice processes, I had already provided technical assistance to this Belgian municipality regarding indigenous peoples' rights issues and through my long-term ethnographic work I had built up relationships of trust with several Q'eqchi' leaders and communities in these regions.

In fact, my first encounter with the Chixoy river (Figure 2) was in 2002 in the context of my master's thesis in anthropology, which focused on the processes of reconciliation and justice in post-conflict Guatemala. I had accompanied two members of a local NGO working on traditional agricultural practices in the Q'eqchi' region on a trip to Chamá Grande, a remote community. In order to reach Chamá Grande, which was known to have been severely hit by the armed conflict, we needed to hike for almost five days, taking the trail that starts at the Pueblo Viejo-Quixal hydroelectric site of the Chixoy dam located at the confluence of the Río Negro and Chixoy rivers. For the first two days we followed the trail at an altitude of almost $1200 \mathrm{~m}$, which gave a breathtaking view over the wide Chixoy river far below us. During this hike, I learned from the two Q'eqchi' NGO members, of whom one was a renowned aj ilionel or spiritual guide and healer, that this impressive river played a crucial role during the State-led violence in the 1970s and 1980s. I already knew about the destructive impacts of the construction of the Chixoy dam, but I learned that as the river forms a natural frontier between two departments. many $Q^{\prime}$ eqchi' from the Alta Verapaz department were not able to cross the river after the army attacked their villages and were stuck for months and even years in the mountains surrounding the river. The Chixoy river was also a clandestine mass grave as many times the army used it to dispose of the bodies of the massacred villagers. 


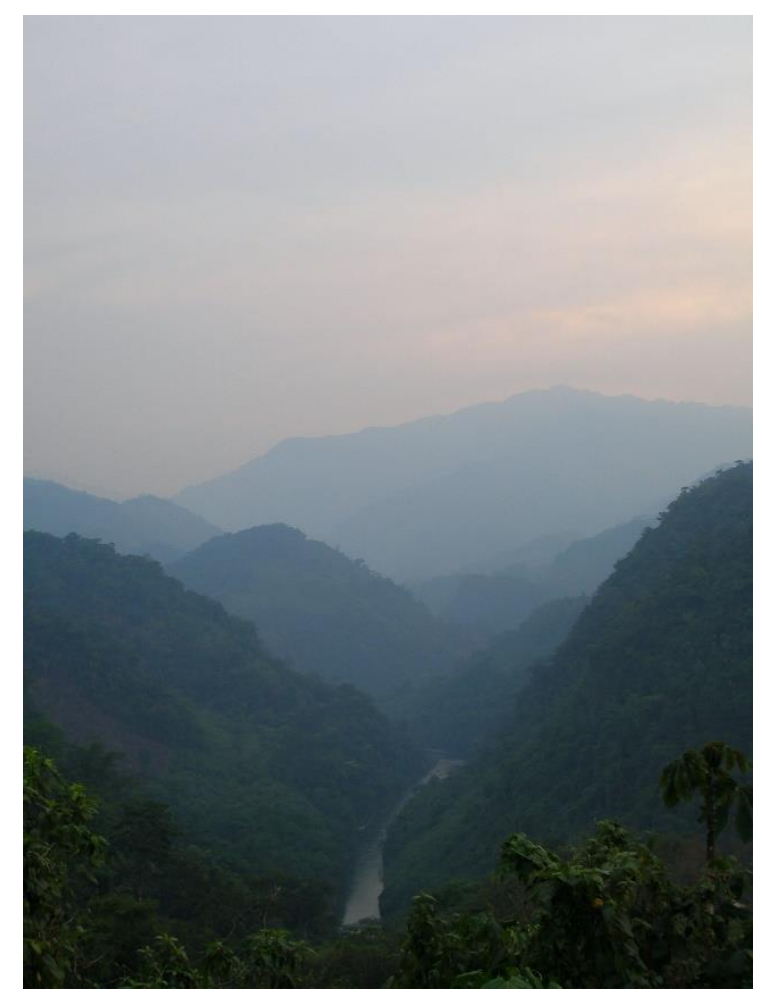

Figure 2. Chixoy river (credits Lieselotte Viaene, 2007).

At the moment of starting the collaborative research in 2014, the Nimlaha'kok microregion, which encompasses some 25 communities and 8000 people, had not yet organized a Popular Consultation like the other dam-threatened communities on the El Quiché side of the river, but were now experiencing increased pressure from INDE and other state institutions to give their consent to the Xalalá project. For example, in May, a military and police convoy entered the region without prior notification, which was perceived as an attempt to militarize the zone. The technical support team of this 'city-to-city link' cooperation program, based in the Nimlaha'kok community, together with the regional second-level Community Development Council (COCODE) - the highest regional authority-expressed their great concern to the Herent municipality and requested technical advice about their individual and collective rights as indigenous peoples. There was also the desire to have a written report that could give international visibility to their situation. The requested human rights assessment resulted in a comprehensive 130-page policy report, which tried to respond to these concerns (In the words of the Herent municipality, the goal of the report was to "encourage an open and participatory discussion on the obligations of the States to protect and respect the human rights of indigenous peoples, the future of natural resources and development from a local community perspective, and the strengthening of their self-government". See: Departamento Norte-Sur, Municipalidad de Herent-Bélgica, "prólogo", in [20]).

The research objectives, methodology and agenda were defined by the Q'eqchi' community members (Figure 3), the technical team and the president of the COCODE, under the guidance of the Belgian municipality and in coordination with me (The main goals were: 1) collecting information on the current socio-political situation and legal advances regarding the protection of the rights of indigenous peoples, specifically the collective right to FPIC; 2) gathering objective and correct information on the content and progress of the Xalalá project; 3 ) collecting information on the current social situation in the regions potentially affected by the Xalalá project; and 4) researching Q'eqchi' perceptions of consultation and other core rights that were at risk from an indigenous perspective.). This included a six-week research visit between May and June 2014 during which individual interviews, focus groups, workshops and meetings with local, national and international 
key stakeholders were held (As I previously worked at OHCHR-Ecuador, and FPIC was one of our main topics of technical assistance to the government and civil society, at the request of the technical team and local authority I organized three training workshops regarding FPIC with the various local authorities). The preparation of the research agenda and the organization of distinct activities in the $\mathrm{Q}^{\prime}$ eqchi' region was directly coordinated with the technical team and with the regional COCODE. All these activities were carried out in Spanish with simultaneous translation into Q'eqchi' with the support of a Q'eqchi' anthropologist and members of the technical team. We jointly visited several communities on both sides of the river and held community and focus group meetings with indigenous local authorities (men and women). We also held meetings with ACODET and with several local NGOs.

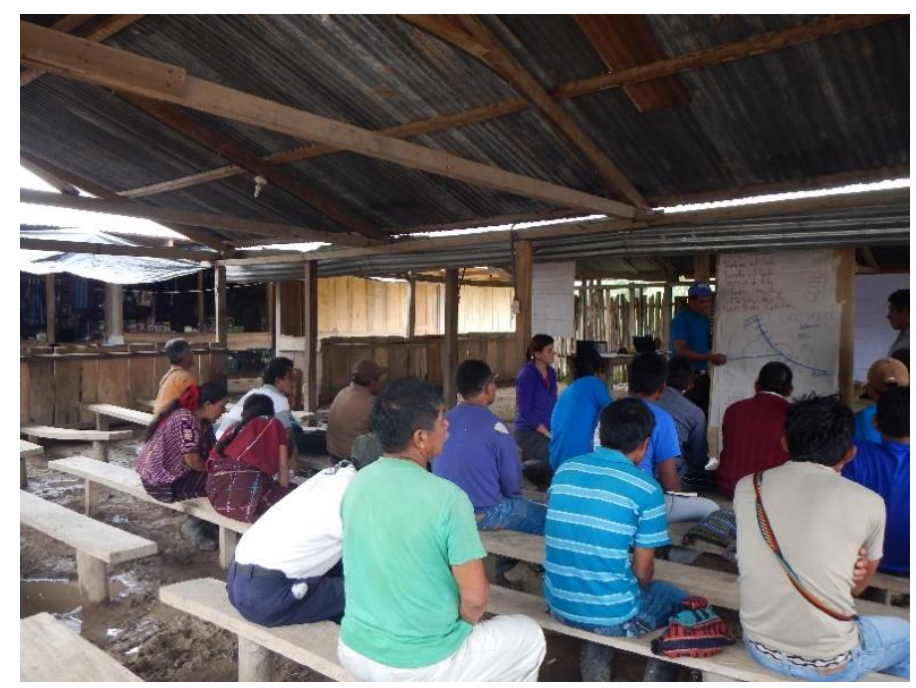

Figure 3. One of the collaborative workshops with dam-threatened Q'eqchi' communities (credit Lieselotte Viaene, 2014).

During this research stay, the Xalalá dam project was highly politically charged, with a corruption scandal about the signed contract between INDE and the Brazilian company widely discussed in the national press. Moreover, INDE's military-trained project manager and his team were anonymously accused in one of Guatemala's main newspapers of coordinating an Illegal Corps and Clandestine Security Apparatus (CIACS) to obtain the approval of the dam-threatened communities. As one of the goals of the human rights assessment was to obtain as much official information as possible about the project management plans, because there was a severe lack of information and complete distrust of INDE and other state institutions, I had several meetings and personal interviews with INDE's project manager, based in the capital, the coordinator of the INDE social management team for the Xalalá project in Cobán. Further, I was invited to visit the INDE technical site in Santa Cruz Verapaz, where the INDE team of technicians and social workers were based. I also held meetings with key state agencies such as the Ministry of Energy and Mining (MEM) and the Presidential Planning and Programming Secretariat (SEGEPLAN).

The main title of the final version of the policy report was: "What will happen with our sacred river and sacred lands?" [20] (Figure 4), because that was one of the main concerns that I heard over and over again when I listened to the many Q'eqchi' elderly women and men and war survivors when they talked about this dam project (During the writing phase, as part of the participatory approach of this research a draft of the report was shared and discussed with the community authorities before its digital publication in March 2015.). The report included a chapter with a legal anthropological analysis of both collective and individual rights: The rights to land, territory and natural resources, the right not to be forcibly displaced, the right to water and food, which derives from the right to an adequate 
standard of living, the right to FPIC and the right to cultural identity. The report also included recommendations to the main stakeholders (state and international cooperation).

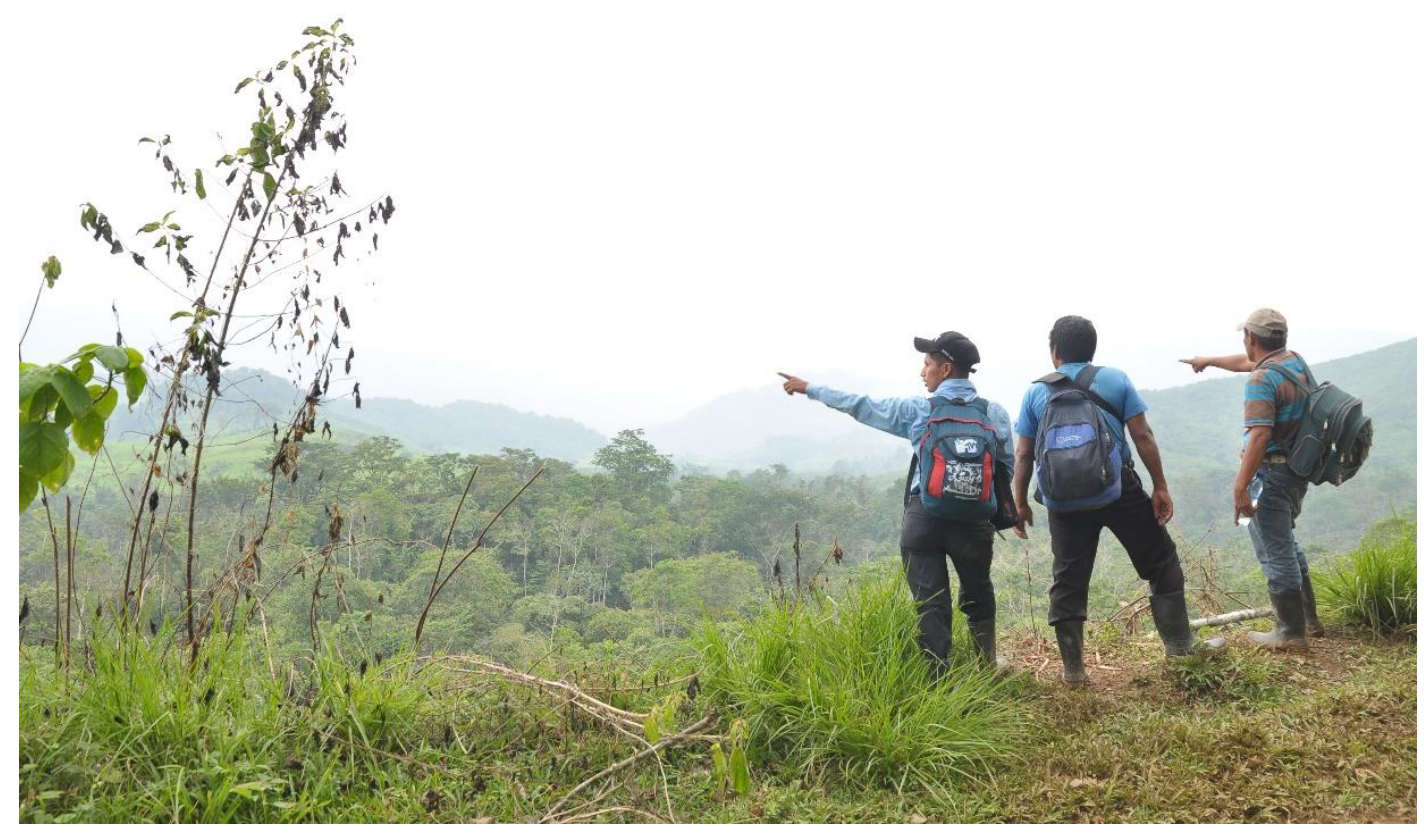

Figure 4. One of the areas to be flooded by the Xalalá dam project (credit: Lieselotte Viaene, 2014).

In March 2015, in coordination with the Q'eqchi' technical team and the COCODE of the Nimlaha'kok region, the policy research report was publicly presented and discussed during a three-week tour, first in the dam-threatened communities on both sides of the Chixoy river, then during a national event in coordination with several indigenous and human rights organizations, such as the Association of Indigenous Lawyers-Nim Ajpu (The local presentations were bilingual and all public presentations were also broadcast live by the indigenous community radio Nimlaha'kok, which reaches not only the communities in the Cobán area but also those on the other side of the river. To further disseminate the report, several blogs were published in Guatemala's leading social media platforms working on social justice issues). These presentations took place in a highly politicized atmosphere amidst several severe social conflicts in the country about extractive hydropower and mining projects in indigenous territories. In fact, at the end of the public event in the capital, the discussion panel and the more than 200 participants were informed that during the event, on the doorstep of the hotel where the report was presented, two well-known indigenous leaders of the hydroelectric opposition in the department of Huehuetenango, Rigoberto Juarez and Domingo Baltazar, had been arrested by the National Police [29]. Both men remained as political prisoners of the Guatemalan State for a year [30]. Water conflicts over extractive development projects were continuing in 2017 when follow-up collaborative research was conducted for six weeks in the same region to learn more about indigenous human-life-water relationships [31].

These days, the Xalalá dam project no longer stands at the top of Guatemala's energy development agenda because of the corruption scandal about the $\$ 5$ million contract between INDE and the Brazilian company to conduct the geological feasibility studies, as well as the determined resistance of the dam-threatened indigenous communities. However, despite Guatemala's violent history of dam-building, the country is now facing a hydropower boom through public-private financing. Today, Guatemala has almost 1500 MW of installed hydropower capacity. Nevertheless, according to the National Electricity Commission by 2027, the country's energy demand will increase by approximately $3000 \mathrm{MW}$, i.e., twice today's consumption [32]. According to the International Hydropower Association, the 
country's hydro resources have the potential to add roughly $11 \mathrm{GW}$ of hydropower capacity, of which $6 \mathrm{GW}$ is technically exploitable according to the Energy Ministry [33]. However, the country and specifically the Alta Verapaz department, whose majority population is Maya Q'eqchi', is facing many water conflicts because of the ongoing hydropower boom in indigenous territories. A recent human rights report documented five large hydropower projects in Guatemala, each affecting at least 20 indigenous communities. Of these, the Renace complex of four powerplants on the Cahabón river in Alta Verapaz is the most contested as it affects 30,000 Q'eqchi' [34].

\section{Water Pluralities: Water beyond a Natural Resource and a Human Right}

By interweaving the different ethnographic accounts resulting from my diverse research projects in this section, I will critically and empirically unpack not only the anthropocentric boundaries of the hegemonic human rights paradigm, but also some of the ontological differences between indigenous and Euro-Western legal conceptualizations about water, rivers, mountains and life. This complex multi-layered ethnographic landscape of the Xalalá water conflict, like many others in indigenous lands and territories around the world, raises fundamental challenges regarding the anthropocentric boundaries of the human rights paradigm. Further, as previously stated elsewhere:

They question dominant modern ontology culture/nature, mind/body, human/nonhuman, belief/reality divides. For indigenous peoples, the world is non-dual: Everything is one, interrelated and interdependent. There is no separation between the material, the cultural and the spiritual. In addition, everything lives and is sacred: Not just human beings, but also hills, caves, water, houses, plants and animals have agency [35].

\subsection{The Xalalá Dam, Another Nimla Rahilal or Deep Suffering and Pain}

"The same thing happened to us in the '80s, when we wanted land, the war started. The same thing is going to happen now. INDE doesn't make it clear what problems it's going to bring."

(COCODE leader, Focus group 2014)

The conversation, workshops and focus groups for the human rights risk assessment revealed that for many dam-threatened Q'eqchi', the Xalalá project is perceived not as economic development, but rather as a new mechanism to dispossess them of their ancestral lands, part of a continuous history of dispossession and displacement that they have suffered since colonization. The Q'eqchi' have been systematically deprived of their territorial rights in order to satisfy the economic interests of national and foreign landowners, the military, agro-industrial companies and drug traffickers [36]. Many participants were survivors of the massacres of the counter-insurgency, witnessed first-hand the scorched-earth policies against their communities and endured the imposition of the civil self-defense patrol system. It is estimated that in the region of Cobán, included in the area of influence of the Xalalá dam, they suffered at least 23 massacres and 36 of their communities were destroyed (this number is retrieved from the information gathered by Alfonso Huet during his collaborative study with genocide survivors in the region and matching it with INDE's map of Xalalá's impact zone. See [37] and Figure 1). As a consequence, the vast majority of the $Q^{\prime}$ eqchi' living in the zone of influence are internally displaced persons or returnees who lived for many years as refugees in Mexico. Moreover, according to INDE 80 percent of the people living in the impact zone do not possess secure land tenure titles.

Many Maya Q'eqchi' denote themselves as aj r'al ch'och, which literally means "sons and daughters of the land", which expresses a deeply reciprocal multi-layered relationship with the land they live on. Together with loqlaj, which is commonly translated as "sacred", and junajil, which means "oneness", this refers to the interdependency between humans and the diverse visible and non-visible natural elements, in which well-being is not centralized to human beings nor does it start from the human but is indivisible between human beings and these "more-than-human" elements. It did not therefore come as a surprise 
that during the meetings many people referred to the Xalalá dam as another nimla rahila or deep suffering and pain. In the words of a Q'eqchi' elder: "this project is another nimla rahilal for us, because just like in the 1980s, we human beings, the sacred hills and valleys and Mother Earth are going to suffer a lot". During my PhD fieldwork in the mid-2000s, I learned that Maya Q'eqchi' refer to what has been conceptualized by Western social and legal scholars as "internal armed conflict", "genocide" and "gross human rights violations" as nimla rahilal, which means severe suffering and pain, localized not only at the individual physical and emotional level, but also at the collective level of the communities and the relational level with what is perceived to be "sacred" or "having dignity" (loq laj).

In Q'eqchi' language, there is no literal translation for the legal concept of violation of a (human) right. During collaborative ethno-linguistic research focused on concepts, expressions and views concerning the war, post-conflict processes and transitional justice mechanisms, I learned that the Q'eqchi' verb muxuk refers to the desecration, transgression or violation of what is sacred and has dignity. Thus, this verb is used to refer not only to the sexual violation of humans, but also to the desecration or violation of non-human kinfolk such as the Tzuultaq'a, maize, a river, a spring, a rock, a tortilla or a house by displaying unacceptable behavior. The bombings of the Tzuultaq'a, the dead bodies in the Chixoy river, the burning down of the maize fields are, from a Q'eqchi' ontological point of view, not just environmental damage but violations of the life of these sacred more-than-humans. As an elderly woman explained in 2007: "Muxuk has been done in various ways; they [the army] dishonoured all the sacred hills [Tzuultaq'a]. Because they threw big bombs, big grenades on the sacred hills, the sacred valleys, true, there we saved ourselves in the sacred hills, the mountains have a deity, true and we defended ourselves over there. Everybody defiled our dignity." Elsewhere, I have argued that for many Q'eqchi survivors, victims and ex-Civil Defence Patroller (PAC) members, the violence they suffered during the armed conflict goes beyond the individual, collective and human field and also involves what are now increasingly called the more-than-humans, such as mountains, rivers, maize and animals $[38,39]$.

Members of the Q'eqchi' community therefore see the construction of the hydroelectric dam, which would imply the construction of a large water reservoir, as another nimla rahilal, not only because of the massive displacement this will provoke, but also the destruction of the fertile lands, the many sacred caves and hills, the sacred maize fields, the killing of the family unit of the river Chixoy and the pollution of farmlands and the community's water sources, provoking hunger. In this region, there are many caves that the spiritual guides use for performing mayejak or sacrificial fire ceremonies to make their petitions to the Tzuultaq'a. Moreover, loqlaj ixim, or maize, is not only a substantial food supply for the Q'eqchi' but is sacred and alive. As described elsewhere, the destruction of the maize fields during the conflict by the army and civil patrollers is not only perceived by the survivors as a violation of the human right to food, but as a desecration of the sacred plant. Around the planting and harvesting of maize, numerous rituals are performed to treat this plant with respect and dignity, because it is alive and also has its energy or spirit. In fact, the energy of the maize is even stronger than the spirits of other crops, which is why the Q'eqchi' sometimes call it "xtioxil li ixim" or "God" of maize (When Q'eqchi' refer to "God", this needs to be understood on the basis that the idea of a personal, transcendent God is not inherent in their cosmovision or ontology; however, many do not ignore the Christian God, as the majority of Q'eqchi' are Catholic) [40-42]. For this reason, under no circumstances should one step over the maize or throw seeds on the ground, nor should one put the basket of tortillas on the ground without a leaf or sack underneath. An important ritual that takes place the night before planting is what the Q'eqchi' call the "watching of the seeds" or yolek. The goal is that the maize seeds "have happiness in their hearts", because if this is achieved, they will all germinate and produce healthy maize plants. During this ritual, the seeds "are being born" (yalaak) and therefore need light, because "the seed cannot be born in the dark". Since maize has an energy, there is a risk that when the seed is neglected, it may "get scared", lose its spirit and not germinate. As many survivors explained during 
my Ph.D. research, "the maize is crying" when it was burned down during the scorched earth campaigns, and this would happen again when the Xalala dam is constructed. The construction of the dam and the reservoir will not only destroy large areas of fertile fields and maize crops, but also block the watering systems from the river to the maize crops. As will be discussed in the next section, this will have a negative impact on the reciprocal and interdependent relationship of maize with the $Q^{\prime}$ eqchi' as human beings.

During focus group meetings with elderly widows of the armed conflict that I organized in 2007, many said, referring to the violence, "we no longer want to suffer, we want tranquillity (tuqtuukilal)". In one of the meetings for the policy report in 2014, one of the indigenous authorities put it this way: "We don't agree with the Xalalá project because the government is already doing too much. In the 1980s we suffered the conflict, we can't take it anymore, we're tired of it." This deep desire to feel and live in peace in their hearts, in their community, in their intimate relationship with the land, the caves and the water, is undermined and threatened once again by this megaproject in their territory. The Q'eqchi' were very concerned about the future, thinking not only about the short-term negative impacts but also about the future of their children and grandchildren. "Where will our children live? Where will they cultivate their maize field?", they ask aloud.

\section{2. "Loqlaj Ha Yoyo'", Water Is Life and Is Alive \\ "The hills began to emerge from the water and at once they became great mountains."}

(Popol Vuh)

While "water is a unique resource" and "without water there is no life" have become mainstream opening mantras of academic and policy publications discussing the numerous water controversies in different parts of the world, as well as the global water crisis that is threatening our planet, according to Maya Q'eqchi' ontologies it is also alive. As a Q'eqchi' elder explained, "water is the blood that flows in both women and men. Without water, the sacred hills and valleys cannot live and neither can human beings or animals." As pointed out above, in Q'eqchi' ontology, water is not perceived as an indep endent natural element but has an ongoing and interdependent relationship with the human beings and the more-than-humans, such as the land, the maize crops, the different water bodies and the animals. The Popol Vuh, regarded as a foundational written narrative of Maya oral history, which survived the book-burning campaigns of the Spanish conquistadores, explains that before the Earth there was a primordial silence in which there was only the sky and the calm sea. The Earth came into being when "the hills began to rise from the water and immediately became huge mountains". In other words, water gives life to the earth, human beings and all the other inhabitants of this planet. Given this, it is not surprising that the dam-threatened Q'eqchi' claim that "without electricity you can live, but not without water". Or as an elderly woman put it, "water belongs to everyone and is vital, many people are going to suffer".

The community members expressed their fear that the Xalalá dam would negatively affect the water sources that feed the streams in the region of the Chixoy river, which are vital for their agriculture and woods. According to the participants, its destruction would provoke struggles and conflicts among the community members over the scarcity of this vital element. The women also indicated that the lack of access to water would bring great poverty; as one Q'eqchi' woman explained, "it brings poverty if we cannot use the water". In addition, people stressed that water is fundamental for the survival of animals, both wild animals living in the mountains and domestic animals, which were going to die. As one Q'eqchi' woman said, “the animals too, where are they going to get water to live?" Furthermore, they feared that contamination or total destruction would have negative impacts on their agricultural systems and the forest. The disappearance of the water sources would also impact on their spiritual practices because it would prevent them from performing the necessary rituals of giving food, wa'tesinq, to the water sources to ask for permission to use them. 
During my follow-up stay at Nimlaha'kok in 2017, the region was facing a drought. This implied that there was no water running through the pipes in the wooden houses and the only water source for the whole community, almost 50 families, was a small stream ten minutes' walk from the center of the community. In order to ensure that all families would have access to the stream, the community authorities had elaborated a time schedule for its access and use. In the early morning before 6 am, the men could go to fill the water jars in order to supply their households with water during the day. Between 6 am and 3 pm, women and children could go to the stream for personal bathing and washing clothes. After that time slot, men could go for a personal bath in the evening. This drought had a major impact on the organization of the families, and not having water for such an extended time became the main subject of our workshops and discussions.

During the different collaborative workshops (Figure 5), the significance of water for the Maya Q'eqchi' was further discussed: Water is alive. Women have a special relationship with water; as a Q'eqchi' woman explained during a focus group, "without water we [women] cannot work. From the moment we get up, make coffee, wash, prepare food... everything is water." The women emphasized that "men hardly work with water, they just get up and wash themselves. Or they wash their hands in a puddle when they come back from the milpa [maize field]." Conversely, women were in daily contact with water and felt its absence more acutely: "water is a life partner, like a husband, it is my partner every day. Without it we cannot live, it is part of our life." For this reason, the Q'eqchi' women said that their voice and opinion would be of utmost importance when the construction of the Xalalá hydroelectric dam was to be discussed.

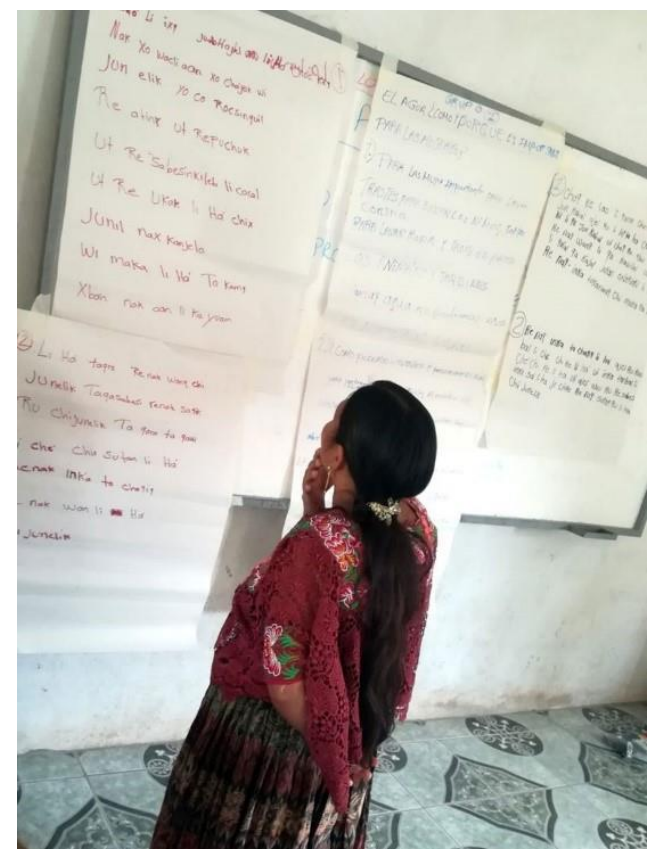

Figure 5. Collaborative workshop with women elders about water's significance (credit: Lieselotte Viaene, 2017).

One of the women elders shared her concerns:

When I grew up there was a lot of water, the little springs never dried up. There were so many fish, that's where we fed ourselves.... they are already blocking the rivers, they are pouring poison into the rivers. We don't respect each other, but we are all the same, children of one God. They're saying that one day the water will run out, that it will only be possible to buy it by the barrel. I'm a widow, how am I going to do that? I can't afford it. 
Elders also shared that in the past they were more in contact or communication with water: "we used to greet the water every day when we went to the mountain to collect it... we were in communication with the water, with the stars." They used to undertake the mayej, the ceremony to ask for permission. As one woman elder put it, "we were paying (tojok) with pom (incense) and candle to the water, to have permission to use it". The reverence and care for water, a being, as they said, who never sleeps, was evident. One woman elder said:

My grandmother carried a candle and pom to ask the water's permission, so that people and water would not feel shocked when they met. The grandmothers said you must greet the water. Cho na, so that it doesn't get scared. There were words you had to use to greet the water before you started your day.

The perception of water and rivers as living beings was clear: Water gives life but is also alive. As one of the other women elders said, "the river has a heart, it lives, it has veins. My grandparents used to say, the veins are like the streams that come out of the big rivers. Water is the sweat of the earth. It does have a heart. If it didn't, it wouldn't be alive."

\subsection{Violations of Multiple Life Systems: Human Beings, Water Bodies, Mountains, Maize, Animals \\ "Rivers are the veins of the earth. A dam will cut the veins, so the river, the earth and us, we all die."}

(Maya Q'eqchi' elder 2017)

A human rights assessment through the dominant Euro-Western lens would limit the rights at risk to, amongst others, the human right to water-access to water sources destroyed - and the human right to food-crops destroyed. However, the ethnographic landscape-multi-layered with sometimes contested and even contradictory meaningsdescribed above shows that these legal conceptualizations stand in strong contrast to complex Maya Q'eqchi' legal norms and practices rooted in their ontology as for them this impact goes far beyond the human: the lives of the "more-than-humans" are at stake. During my collaborative work on the genocide and transitional justice, I learned through the understanding of nimla rahilal that the Maya Q'eqchi' survivors assign to the conflict that its impact goes beyond merely human rights violations of individuals and human beings. The Q'eqchi' knowledge of the impact of the construction of the Xalala dam points to the same ontological understandings. One of the elder spiritual guides explained in 2014 that the Chixoy river, which is the main river, the smaller side rivers, and the fertile river banks together, formed one family unit: A mother, a father and children. Thus, the Xalalá dam would destroy this nuclear family and violate the life of the Chixoy river: $x m u x^{\prime} b a l$ yuam nimla ha. As large rivers have, according to the Q'eqchi', very strong energies, "the river will feel pain and suffer". As described above, the hydroelectric project would deeply transgress and violate the sacred value and dignity of the river and the other interconnected elements such as the lands, side rivers and animals living in the rivers.

Elsewhere, I pointed out that as part of Maya Q'eqchi' legal order, "an internal logic of the cosmos that, through an invisible spiritual force, fosters a new tuqtuukilal or tranquillity" [38] exists, which is known as q'oqonk (stem is q'oq). In the case of the sacred maize, when someone disrespects, desecrates or defiles maize, it causes a disharmony in the spiritual relationship with this sacred food. Thus, the maize suffers and feels pain, for which "the sacred maize is crying". In fact, during the armed conflict the systematic cutting and burning of maize by the military and ex PAC not only caused famine among the displaced groups who sought refuge in the mountains, but also implied the destruction of the spiritual basis of the Q'eqchi'. According to the elders, the accumulation of sadness from the destruction of so much sacred maize for no reason provoked a strong reaction by their energies-spirits, which was expressed in poor harvests for many years after the armed conflict. As one old woman explained in a focus group in 2007, the sacred maize also made her q'oq: "How much q'oq of the sacred corn that was cut by the military. That's 
why it is so hard what we are suffering now... That's why the maizefield grows so little, it is very small."

Within the context of the construction of the Xalala dam, the elders were very clear that the river and the sacred mountains or Tzuultaq'a will react or take revenge for the damage done when humans do not treat them with respect and dignity they deserve. During the workshops for the policy report, the elders shared several narratives about people who drowned in the Chixoy River, for example former PAC chiefs who abused their power during the armed conflict. Moreover, several community members talked about recent landslides in a community in the Ixcán municipality on the other side of the river, which destroyed parts of that community. For non-Q'eqchi' people, these landslides are perceived as natural disaster, but many $\mathrm{Q}^{\prime}$ eqchi' community members attributed them to a reaction of the Tzuultaq'a - the mountain has called-because of the population's favorable attitude to the construction of the Xalalá hydroelectric plant and for having stopped practicing their Q'eqchi' ceremonies as they converted to an evangelical church.

This negative reciprocity, or "Maya Q'eqchi' scientific law", is already unfolding according to Q'eqchi' elders who participated in the workshops in 2017. One of the elders said, referring to the many hydroelectric dam projects in the region, "now they are cutting the veins of the earth because of the construction of the hydroelectric plants", but "if they cut the river it will dry up. It's as if the blood in your body dries up, it's similar to what happens with water." In fact, one of the elders explained the deep-rooted causes of the drought they were facing in the region as the "water is withdrawing because of deforestation. We're killing the water ourselves. Our own pollution and negligence hurt the water, that's why the water gets angry, that's why the community stream dried up. Water sends us this sign that it is not happy, that it is sad."

The elders recognized that it was partly a problem of education and intergenerational transmission of knowledge: "we are all guilty, we do not tell the children how to take care of the sacred water... these ideas are hard to speak about and to understand, young people do not believe us." The women elders lamented along similar lines: "now water comes to the houses in pipes, we no longer greet the water" ... "Young people do not know the sacred sites of the river so they do not ask for permission and they violate the life of the river (xmux'bal yuam nimla ha)". The elders also recognized the negative effects of population growth and contemporary habits, saying that villagers cut down trees close to the springs and observing pollution "from plastics, soaps, pesticides, garbage". The elders asked "why should children say good morning to the water if it comes from a pipe? When we were young we had to go to the hill to get water, it was a law to greet the water. Now young people don't respect those ideas, they don't want to listen... they make fun of us, everything has changed."

However, respecting and taking care of these non-human kin is vital for keeping them alive. As one Q'eqchi' elder explained, "when you go to a sacred place, you are not going to make a mess, to sully it. You have to go there asking permission, respecting it as if it were a person."

\section{Discussion: The Need for Critical Engagement with Plurilegal Water Ontologies}

So far, ontological plurilegalities, such as the described Maya Q'eqchi' plurilegal water ontologies, have been under-theorized in the fields of international human rights law and environmental law. Drawing on the above discussion of the multi-layered ethnographic landscape of Maya Q'eqchi' human-water-life relationships in the context of a human rights risk assessment of hydropower development in territories severely affected by the armed conflict, in the discussion presented in the final section, I call for a new mindset in these international legal fields in order to pave the way for urgent rethinking of the human right to water and, more broadly, human rights by unsettling the modern divides of culture/nature and human/more-than-human. I therefore develop two broad theoretical and methodological perspectives and concerns, which should inform a comprehensive 
new research agenda, giving ecco to the French philosopher Descola, stating that "a good way to understand the status of a scientific problem is to study controversies" [43].

First, I advocate recognition not only of the conceptual limitations of the dominant anthropocentric Euro-Western human rights paradigm in light of the climate emergency and global water crisis, but also of the ontological condition of law. Adopting a pluralistic legal lens is instructive for better grasping the underlying multi-layered, fluid and intergenerationally nuanced indigenous legal orders regarding human-water-life relationships. Second, I argue that once legal scholars embark on a theorization of these complex ontological legalities about the human-more-than-human, this should be critically empirically grounded and undo practices of ongoing colonial marginalization and recolonization of indigenous knowledges and practices.

While this urgent call for a fundamental rethink about ontology and human rights mainly stems from my long-term collaborative encounters with the Maya Q'eqchi, I am currently developing, with the financial support of a Starting Grant of the European Research Council (ERC) [44], a five-year interdisciplinary research project called "RIVERSWater/human rights beyond the human? Indigenous water ontologies, plurilegal encounters and interlegal translation" with the aim to strengthen the foundations of this presented call with innovative pluralist and comparative insights about indigenous legal human-water-life orders in the contexts of Nepal, Guatemala, Colombia and the UN human rights system.

\subsection{Who Is Afraid of Plurilegal Water Ontologies?}

Since my first ethnographic encounters with the Maya Q'eqchi' some 20 years ago, my initial conceptual academic understandings about law and human-water-life relationships have evolved substantially over the different research projects. Through these multiple and not straightforward encounters in the context of old violence-armed conflict and genocide — and new violence - extractive development projects - I learned, amongst other things, that the dominant Euro-Western-centered legal tradition of human rights and international law broadly does not ontologically address multi-layered indigenous peoples' legal conceptualizations, which are embedded in radically different visions and practices about respect for, harm to and violations of human-non-human relationships.

Regarding the old violence, therefore, as discussed elsewhere, dominant transitional justice mechanisms are falling short of responding efficiently to the needs and priorities of indigenous peoples regarding justice, reparation, memory, reconciliation and guarantees of non-repetition $[38,45]$. Regarding the new violence of extractive development projects in indigenous territories, the 2014-2015 human rights assessment policy research report discussed above was another critical turning point in my academic journey, because, even though the research already pointed clearly towards the central ontological political conflict about the Chixoy river and the Xalalá dam, namely a "conflict involving different assumptions about what exists" [46], in my opinion, Guatemalan human rights defenders were not able to sufficiently recognize this "indigenous mode of being" [47] regarding water and land and kept on leaning on the dominant Euro-Western legal human rights framework in their legal fight against this Xalalá dam project.

Reflecting on a report that was intended to honor the ontological visions and practices of the Maya Q'eqchi' in their struggle and on the intrinsic limitations of this kind of human rights policy research report, it is imperative to recall the words of Māori scholar Tuhiwai Smith of three decades ago: the human rights field is also "a significant site of struggle between the interests and ways of knowing of the West and the interests and ways of resisting of the Other" [48]. Indeed, when Maya Q'eqchi' elderly women state that water and water bodies such as springs needs to be respected because they are alive, this should be taken seriously by human rights defenders and scholars and not just a strategic romantic belief that should mobilized to deal with the current environmental degradation. At the same time, it needs to be acknowledged that, as other legal anthropologists have pointed out, "law is a source of constituting and legitimating power" [49], so it defines 
relations of power of people, institutions and organization over other people, institutions and organizations.

These premises about law, power and indigenous ontologies should be taken seriously by the increasing number of critical legal theoretical scholars who interrogate dominant Euro-Western legal positivistic assumptions about anthropocentrism, nature and environment in international human rights and environmental law. As mentioned in the introduction, there is a growing interest among environmental scholars in critically scrutinizing to what extent these dominant assumptions have contributed to the environmental degradation the world is facing and in calling for a rethink regarding how to use human rights and environmental law to mediate the human-environment/natural resources/nature relationship [50-53]. Rights of Nature (RoN), granting legal personhood to nature and its elements, such as rivers, is an emerging transnational legal framework fast gaining international traction among Euro-American legal scholars as a new tool for combatting environmental destruction.

In fact, according to the 11th Annual Report of the United Nations Program of Harmony with Nature there exists now a "mosaic of Earth-centred law for planetary health and human well-being", as at least 35 countries have Rights of Nature legislation and policies in place [54]. Its international proponents are promoting the idea that "ecosystems [including trees, oceans, animals and mountains] have the right to exist, thrive, and evolve" [55], often claiming that RoN is rooted in indigenous lifestyles and views on nature/the environment.

However, so far neither critical legal theory scholars nor human rights and environmental legal scholars have engaged fully with ontological political conflicts about humanwater-life, which water conflicts in indigenous territories demonstrate. The Q'eqchi' were very clear that the Chixoy river, but also the maize and the sacred mountains, have agency, in a positive and negative reciprocal way. Or, as described elsewhere, "when humans harm non-humans or nature, an energy imbalance is created which implies changes in physical life. Global warming, water scarcity, disease and land infertility will appear" [35]. To what extent, therefore, have the proponents of RoN considered the fact that by granting rights to rivers and other natural elements, whilst allegedly drawing on indigenous visions, these elements may also form an agency which might go against the interests of human beings? How will these RoN advocates deal with angry and sad rivers and other water bodies which cause droughts, bad harvests and deaths, as described above? So far, these RoN proponents, generally Euro-Western legal scholars, have generally not considered the possible negative impacts of essentializing and codifying indigenous visions and practices of nature [56]. It seems that these critical legal scholars are afraid to engage deeply with the ontological questions and legal discomfort these water pluralities generate $[57,58]$.

The contested, fluid and sometimes contradictory ethnographic accounts of the Xalalá water conflict demonstrate that the apparently simple concept of water assumes "complex unconscious meanings that need to be consciously sorted out" [59]. A crucial task, therefore, is to address the many pressing questions and concerns that remain unanswered regarding multi-layered human-water-life relationships and meanings in contexts of human rights assessments of water conflicts in indigenous territories.

How do diverse indigenous peoples perceive and relate to water in daily practice in contexts of a continuation of colonial and racialized violence in their territories? What is ontologically at stake if indigenous peoples lose access to the continuous flow of rivers or to water sources due to these extractive projects? Regarding human rights assessments of risks arising from extractive development projects, an important question is whether the obstruction of the continuous flow of rivers by hydroelectric dams should be legally conceptualized as a violation of the human right to life, enshrined in the Universal Declaration of Human Rights and the International Covenant on Political and Civil Rights, instead of the human right to water? Or should these rivers be granted legal personhood, as the international movement of RoN is promoting? How do water and water bodies, such as rivers, speak in the midst of sociopolitical conflicts provoked by extractive development projects? Another crucial question is to what extent will indigenous legal conceptual- 
izations of the damage to rivers, mountains and other natural elements produced out of the analysis of dreams, fire ceremonies, consultations of sacred sites or bird songs be accepted as objective and scientific proof for legal practitioners during litigation in court or consultation (FPIC) processes?

Legal scholars who are embarking on this de-anthropocentric and ecocentric turn could draw useful lessons from the critical insights and ongoing debates about what has been coined as the ontological turn in social sciences. While this is a blind spot in international law and human rights scholarship, different fields in social sciences, such as Science and Technology Studies [60-63] and multispecies ethnography [10,64,65], have already embarked on unsettling dominant modernist ontological assumptions and conceptualizations of culture/nature and human/more-than-human relationships and theorizing about the agency of non-humans, more-than-humans, other-than-humans. It is therefore imperative to create spaces for open and critical dialogue between mainstream human rights theory and these emerging theories and social science contributions.

At the same time, I propose that the adoption of a pluralistic legal lens would enable a critical analysis of the above-mentioned broad questions and multiple contestations over hegemonic, counter-hegemonic and ontologically legal understandings and indigenous practices of human-water-life relationships in different legal arenas. The conceptual framework of legal pluralism $[66,67]$ - the existence of a plurality of legal orders stemming from different sources of legitimation within one sociopolitical space-is "an important element of the contexts in which human rights operate" [68].

In daily life, this plurality of legal norms is shaped by interconnectedness or interlegality $[69,70]$ and legal pluralism provides "a useful way of conceptualizing the interaction of all these various norm assertions and their potential efficacy" [71]. At the same time, it should also be acknowledged, following the Canadian indigenous scholar Val Napoleon, that there is a need for deeper and more critical understanding of the strengths and principles of indigenous legal orders and how these can be used to deal with these multi-layered human-water-life rights issues [72].

\subsection{A Call for Bottom-Up Co-Theorizing about Human/Water beyond the Human \\ "We don't have education, but we do have our ideas, thoughts and knowledge. This rules here."}

(Q'eqchi' authority, workshop, 2014)

A crucial methodological concern arose through my different collaborative academic and policy research projects with the Maya Q'eqchi': How to conduct empirical research into different conceptions of human-water-life that do not lead to the recolonization/appropriation of indigenous knowledge by non-indigenous scholarship and public policy. Currently, a welcome "empirical turn in international legal scholarship" [73] is unfolding, which goes beyond the classical doctrinal method, a turn that is visible in the growing number of handbooks $[74,75]$ about research methods and human rights, and in interdisciplinary methodological courses in legal training at universities, some important insights and lessons are needed to undo the role of legal scholarship in the ongoing oppression and marginalization of indigenous knowledge and practices. In the 1990s, Māori scholar Linda Tuhiwai Smith critiqued the "positional superiority of Western knowledge" [50] in academic knowledge production and the growing indigenous scholar community has been pointing out this continuing lack of recognition of indigenous knowledge as scientific knowledge [76]. For example, regarding the above-mentioned popular but contested ontological turn, Canadian Métis scholar Zoe Todd writes about the "ongoing structural colonialism within the academia" [76] (p. 4) because this Euro-Western academic ontological narrative spins on the back of non-European thinkers and practitioners without giving real credit to indigenous peoples.

In the discipline of law, indigenous legal scholars have also indicated that, despite the progressive advances in recognizing the collective human rights of indigenous peoples, in practice Eurocentric thinking, liberal individualism and Western legal culture continue to 
dominate their interpretation and application, making it difficult to realize their substantive self-determination [77]. For example, indigenous knowledge is still marginalized to "uses and customs", "customary law" and "infra-legal phenomena" in the mainstream legal and human rights field [77]. Throughout my ethnographic encounters, many elders shared the above-mentioned concern, that because they do not master Spanish and never went to school, their knowledge and wisdom about the armed conflict and the dam's impact is ignored and neglected by non-indigenous governmental officials, but also often by NGO collaborators and their own youth. Intimately connected is the fact that legal scholarship, and academia more broadly, have not sufficiently addressed "institutional racism" [78] or its racial colonial legacies inscribed in legal theories and philosophies that have given birth to the human rights field [79]. For example, regarding human rights risks assessments, one of the mayor concerns of indigenous elders, as explained above, is about taken seriously their indigenous knowledge and ontologies about harm and violations as legal evidence in impact assessments and court rooms.

Regarding research projects related to indigenous peoples, the former United Nations Special Rapporteur of the Rights of Indigenous Peoples, Vicky Tauli-Corpuz, observed:

Many academics, they come to collect the data and they use it to promote their career and in the end it is not helping the [indigenous] people that have been the 'objects' or 'subjects' of their research. It does not fit the framework that they have, ... I think that is really sad and that is one part of the problems that indigenous peoples face, when the academia become the 'experts', and they always refer to them as the experts. When in fact, they gather all those things from indigenous peoples. So, I think the call is for the academia to acknowledge that the indigenous peoples from whom they collected this information are the experts [80].

She recommends the participatory action research (PAR) framework $[48,81,82]$ that has been developed because:

This is really the framework that you need to work together with the people who are at the core of your subject, and then you really need to ensure that their views come into the whole framework. This is the basic thing, that the research is going to be done with the goal in mind of further enhancing the capacities of these peoples to be self-determining, to be able to have the capacity to assert that they should have their rights to their territories. [80]

Indeed, when legal scholars are engaging with empirical work with indigenous peoples, they should take seriously Canadian Métís anthropologist Zoe Todd, who advises avoiding further ongoing appropriation of indigenous knowledge in Euro-Western research, including the use of indigenous ontologies without acknowledgment of indigenous thinkers, and the invisibility of indigenous scholars from European research settings [76]. So indeed, it needs to be recognized that law is "not just rules, but a complex set of intellectual, social, political, and ethical practices" [83]. Against these broader metrological concerns about the necessary process of decolonizing research methods, I urge that legal theorical research, when embarking on an empirical turn about human rights, such as the human right to water, RoN and environmental law, should also support indigenous peoples to reclaim control over their own ways of knowing, being and living.

Funding: The writing of this article was possible thanks to the following funding (chronological order): PhD research project (2006-2010) “Cultural context and transitional justice: the role of non-western legal traditions in dealing with gross human rights violations in post-conflict countries"Research Fund Flanders (FWO)_Belgium; Municipality Herent, Belgium (2014,2015); Marie Curie Individual Fellowship (2016-2018) GROUNDHR-Challenges of Grounding Universal Human Rights. Indigenous epistemologies of human rights and intercultural dialogue in consultation processes on natural resource exploitation (Grant Agreement 708096) and ERC Starting Grant (2019-2024) RIVERSWater/human rights beyond the human? Indigenous water ontologies, plurilegal encounters and interlegal 
translation, (Grant Agreement 804003), under the European Union's Horizon 2020 research and innovation program.

Institutional Review Board Statement: All research projects were conducted according to Ethical Guidelines for Good Research Practice' (1999) of the Association of Social Anthropologists of the UK and the Commonwealth. The research project GROUNDHR received ethical review and approval from H2020-MSCA-IF-2015, while the research project RIVERS received ethical review and approval from ERC Ethics Committee in 2018.

Informed Consent Statement: Informed consent was obtained from all subjects involved in the study.

Acknowledgments: I am grateful to the anonymous reviewers for their valuable comments and suggestions and also to Rachel Sieder for her support and guidance during the research and writing. I owe my greatest thanks and deepest respect to all Maya $Q^{\prime}$ eqchi' for their kindness, trust, support and generosity through the years.

Conflicts of Interest: The authors declare no conflict of interest.

\section{References}

1. Prensa Libre, "Pérez Molina: Xalalá es una necesidad de nación”. Available online: http://www.prensalibre.com/noticias / justicia/inde-perez_molina-xalala-necesidad_de_nacion-contrato-lesivo_0_1143485775.html (accessed on 1 April 2021).

2. World Commission on Dams (Ed.) Dams and Development: A New Framework for Decision-Making; Earthscan: London, UK, 2000.

3. International Rivers. Dam Standards: A Rights-Based Approach. A Guidebook for Civil Society; International Rivers: Berkeley, CA, USA, 2014; p. 19.

4. United Nations General Assembly: A/RES/64/292 The Human Right to Water and Sanitation. Available online: https:/ undocs. org/pdf?symbol=en/a/res/64/292 (accessed on 5 June 2021).

5. Swyngedouw, E. The Political Economy and Political Ecology of the Hydro-Social Cycle. J. Contemp. Water Res. Educ. 2009, 142, 58. [CrossRef]

6. Sally Engle Merry. Available online: https://www.youtube.com/watch?v=R_mXzgP8YoU (accessed on 5 June 2021).

7. Von Benda-Beckmann, K.; Turner, B. Anthropological Roots of Global Legal Pluralism. In The Oxford Handbook of Global Legal Pluralism; Berman, P.S., Ed.; Oxford University Press: New York, NY, USA, 2020; p. 138.

8. De la Cadena, M. Earth Beings: Ecologies of Practice across Andean Worlds; Duke University Press: Durham, UK, 2015; The Lewis Henry Morgan Lectures 2011.

9. De la Cadena, M.; Blaser, M. (Eds.) A World of Many Worlds; Duke University Press: Durham, UK, 2018.

10. Haraway, D.J. When Species Meet; University of Minnesota Press: Minneapolis, MN, USA, 2008; Posthumanities 3.

11. Whatmore, S. Materialist Returns: Practising Cultural Geography in and for a More-than-Human World. Cult. Geogr. 2006, 13, 600-609. [CrossRef]

12. Grear, A. Deconstructing Anthropos: A Critical Legal Reflection on "Anthropocentric" Law and Anthropocene "Humanity". Law Crit. 2015, 26, 225. [CrossRef]

13. De Lucia, V. Competing Narratives and Complex Genealogies: The Ecosystem Approach in International Environmental Law. J. Environ. Law 2015, 27, 91-117. [CrossRef]

14. Mol, A. Ontological politics. A word and some questions. Editor. Board Sociol. Rev. 2015, 75, 74-89.

15. Law, J. On sociology and STS. Sociol. Rev. 2008, 56, 636-637. [CrossRef]

16. Zoe, T. Fish Pluralities: Human-Animal Relations and Sites of Engagement in Paulatuuq, Arctic Canada. Études Inuit Stud. 2014, 38, 222. [CrossRef]

17. Rose Johnston, B. Large-Scale Dam. In Water Justice; Cambridge University Press: Cambridge, UK; New York, NY, USA, 2018.

18. Botón Simaj, S. ¿De qué Sirve la Luz, para Quienes no Quieren Ver la Luz? Un Primer Acercamiento para Conocer el Proyecto Hidroeléctrico Xalalá y la Identificación de las Comunidades que Posiblemente Quedarían en el Área de Influencia Directa; Pastoral Social del lxcán: Ixcán, Guatemala, 2007.

19. Corte Inter-Americana de Derechos Humanos. Caso Masacres de Río Negro Vs. Guatemala, Sentencia de 4 de Septiembre de 2012, (Excepción Preliminar, Fondo, Reparaciones Y Costas); Corte IDH: San José, Costa Rica, 2012.

20. Viaene, L. La Hidroeléctrica Xalalá en Territorios Maya Q'eqchi' de Guatemala ¿Qué Pasará con Nuestra Tierra y Agua Sagradas? Un Análisis Antropológico-Jurídico de los Derechos Humanos Amenazados; Human Rights Centre, Ghent University: Ghent, Belgium, 2015.

21. Colectivo Ecologista Madre Selva. Características de la Biodiversidad de la Zona del Embalse de la Central Hidroeléctrica Xalalá, Quiché-Alta Verapaz, Guatemala; Colectivo Ecologista Madre Selva: Ciudad de Guatemala, Guatemala, 2008.

22. ACODET y Asociación Puente de Paz. Diagnósticos Comunitarios en Comunidades Amenazadas por la Represa Xalalá: Una Experiencia de Sistematización y Aprendizaje para la Defensa de Nuestros Territorios; ACODET y Asociación Puente de Paz: Ixcán, Guatemala, 2009.

23. International Labour Organization Indigenous and Tribal Peoples Convention 169; International Labour Organization: Geneva, Switzerland, 1989. 
24. UN Declaration on the Rights of Indigenous Peoples; United Nations: New York, NY, USA, 2007.

25. UN General Assembly. Report of the Special Rapporteur on the Rights of Indigenous Peoples, James Anaya; UN General Assembly: New York, NY, USA, 2012; A/HRC/21/47, 6 July 2012, Par. 66.

26. Figueroa, O. Prensa Libre, 30 October 2010: Al menos el $90 \%$ de vecinos rechazan proyectos mineros en Uspantán. Available online: https:/ / www.prensalibre.com/guatemala/comunitario/vecinos-rechazan-proyectos-mineros-uspantan_0_362963872html (accessed on 1 April 2021).

27. NISGUA. Guatemalan Government Restarts Xalalá Hydroelectric Dam Project in Spite of Community Opposition; NISGUA: Oakland, CA, USA, 2013.

28. Rodríguez Garavito, C.A. Human Rights in Minefields: Extractive Economies, Environmental Conflicts, and Social Justice in the Global South; Dejusticia: Bogotá, Colombia, 2015.

29. Prensa Comunitaria Guatemala, Preso Político más: Rigoberto Juárez defensor del territorio, 24 de marzo 2015. Available online: https:/ / comunitariapress.wordpress.com/2015/03/24/un-preso-politico-mas-rigoberto-juarez-defensor-del-territorio2/ (accessed on 1 April 2021).

30. La Hora, Tribunal absolvió a líderes comunitarios, 23 de julio 2016. Available online: https: / lahora.gt/tribunal-absolvio-liderescomunitarios/ (accessed on 1 April 2021).

31. Sieder, R.; Viaene, L. A dying river in Alta Verapaz, Guatemala. Available online: https:/ / rivers-ercproject.eu/a-dying-river-inalta-verapaz-guatemala/ (accessed on 1 April 2021).

32. Ministerio de Energías y Minas (MEM). Política Energética 2013-2027. Energía para el Desarrollo. Calidad, Cantidad Competitividad; MEM: Ciudad de Guatemala, Guatemala, 2013; p. 22.

33. International Hydropower Association (IHA): Country Profile Guatemala. Available online: https://www.hydropower.org/ country-profiles/guatemala (accessed on 1 April 2021).

34. Rights and Resources Initiative \& Amazon Conservation Team. Violated Collective Rights: Guatemala. The Multidimensional Impact of Extractive and Infrastructure Projects. 2020. Available online: https:/ / storymaps.arcgis.com/collections/e72214576af5 49ab94c1d45bd88bbadd?item $=4$ (accessed on 1 April 2021).

35. Izquierdo, B.; Viaene, L. Decolonizing Transitional Justice from Indigenous Territories. Available online: http://www.icipperlapau.cat/numero34/articles_centrals/article_central_2/ (accessed on 1 April 2021).

36. Grandia, L. Enclosed: Conservation, Cattle, and Commerce among the Q'eqchi' Maya Lowlanders, Culture, Place, and Nature: Studies in Anthropology and Environment; University of Washington Press: Seattle, WA, USA, 2012.

37. Huet, A. Nos Salvó La Sagrada Selva. Memoria de Veinte Comunidades Q'eqchi'es que Sobrevivieron al Genocidio; ADICI: Ciudad de Guatemala, Guatemala, 2008.

38. Viaene, L. The Internal Logic of the Cosmos as "Justice" and "Reconciliation". Crit. Anthropol. 2010, 30, 287-312. [CrossRef]

39. Viaene, L. Dealing with the Legacy of Gross Human Rights Violations in Guatemala: Grasping the Mismatch between Macro Level Policies and Micro Level Processes. Int. J. Human Rights 2011, 15, 1160-1181. [CrossRef]

40. De Ceuster, H.P. Prácticas Agrosilvestres Q'eqchi'es: Más allá de Maíz y Frijol; Centro Ak' Kutan: Ciudad de Guatemala, Guatemala, $2011 ;$ p. 85.

41. Haeserijn, E. Filosofia popular de lo K'ekchi' de hoy. Guatem. Indíg. 1975, 10, 44-54.

42. Permanto, S. The Elders and the Hills. Animism and Cosmological Re-Creation among the Q'eqchi' Maya in Chisec, Guatemala. Ph.D. Thesis, School of Global Studies, Social Anthropology, University of Gothenburg, Gothenburg, Sweden, 2015.

43. Descola, P. The Ecology of Others: Anthropology and the Question of Nature; Prickly Paradigm Press: Chicago, IL, USA, 2013 ; p. 7.

44. ERC Research Project: RIVERS—Water/Human Rights beyond the Human? Indigenous Water Ontologies, Plurilegal Encounters and Interlegal Translation. Available online: www.rivers-ercproject.eu (accessed on 1 April 2021).

45. Viaene, L. Life is Priceless: Mayan Q'eqchi' Voices on Guatemalan National Reparations Program. Int. J. Transitional Justice 2010, 4, 4-25. [CrossRef]

46. Blaser, M. Ontological Conflicts and the Stories of Peoples in Spite of Europe: Toward a Conversation on Political Ontology. Curr. Anthropol. 2013, 54, 547. [CrossRef]

47. Jewett, C.; Garavan, M. Water Is Life-An Indigenous Perspective from a Standing Rock Water Protector. Community Dev. J. 2019, 54, 49. [CrossRef]

48. Smith, L.T. Decolonizing Methodologies: Research and Indigenous Peoples; Zed Books, University of Otago Press: London, UK; New York, NY, USA; Dunedin, New Zealand, 1999.

49. The Power of Law in a Transnational World: Anthropological Enquiries, 1st Paperback ed.; Von Benda-Beckmann, F.; von BendaBeckmann, K.; Griffiths, A.M.O. (Eds.) Berghahn: New York, NY, USA, 2012.

50. Peter, B. (Ed.) Exploring Wild Law: The Philosophy of Earth Jurisprudence; Wakefield Press: Kent Town, Australia, 2011.

51. Usha, N.; Kishan, K. Locating Nature: Making and Unmaking International Law. Leiden J. Int. Law 2014, 27, 573-594.

52. Luis, K. Human rights and the environment in the Anthropocene. Anthr. Rev. 2014, 3, 254-275.

53. Lim, M. (Ed.) Charting Environmental Law Futures in the Anthropocene; Springer: Singapore, 2019.

54. United Nations General Assembly: A/75/266 Resolution adopted by the General Assembly on 21 December 2020. Available online: https://undocs.org/en/A/RES/75/220 (accessed on 5 June 2021).

55. Earth Law Center. Available online: https://www.earthlawcenter.org/ (accessed on 4 December 2020). 
56. Viaene, L. Can Rights of Nature save us from the Anthropocene catastrophe? Critical reflections from the field on the emerging ecological jurisprudence. Asian J. Law Soc. 2021, in press.

57. Von Benda-Beckmann, F. Who's Afraid of Legal Pluralism. J. Legal Plur. Unoff. Law 2002, 47, 37-82. [CrossRef]

58. Viveiros de Castro, E. Who Is Afraid of the Ontological Wolf? Some Comments on an Ongoing Anthropological Debate. Camb. J. Anthropol. 2015, 33, 1. [CrossRef]

59. Lewellen, T.C. The Anthropology of Globalization: Cultural Anthropology Enters the 21st Century; Bergin \& Garvey: Westport, CN, USA, 2002; p. 237.

60. Latour, B. We Have Never Been Modern; Harvard University Press: Cambridge, MA, USA, 1993.

61. Latour, B. Reassembling the Social: An Introduction to Actor-Network-Theory; Oxford University Press: Oxford, UK, 2007; Clarendon Lectures in Management Studies.

62. Stengers, I. The Invention of Modern Science; University of Minnesota Press: Minneapolis, MN, USA, 2000; Theory Out of Bounds, v. 19.

63. Law, J.; Mol, A. (Eds.) Complexities: Social Studies of Knowledge Practices; Duke University Press: Durham, UK, 2002; Science and Cultural Theory.

64. Kohn, E. How Forests Think: Toward an Anthropology beyond the Human; University of California Press: Berkeley, CA, USA, 2013.

65. Eben Kirksey, S.; Helmreich, S. The emergence of multispecies ethnography. Cult. Anthropol. 2010, 25, 545-576. [CrossRef]

66. Griffiths, J. What Is Legal Pluralism. J. Legal Plur. Unoff. Law 1986, 24, 1-56. [CrossRef]

67. Schiff Berman, P. The Oxford Handbook of Global Legal Pluralism; Oxford University Press: New York, NY, USA, 2020.

68. Corradi, G. Human Rights and Legal Pluralism: Four Research Agendas. In Human Rights Encounter Legal Pluralism: Normative and Empirical Approaches; Corradi, G., Brems, E., Goodale, M., Eds.; Hart Publishing: Oxford, UK; Portland, OR, USA, 2017; p. 3, Oñati International Series in Law and Society.

69. De Sousa Santos, B. Toward a New Legal Common Sense: Law, Globalization, and Emancipation; Butterworths: London, UK, 2002.

70. Hoekema, A. European Legal Encounters: Cases of Interlegality. J. Legal Plur. 2005, 51, 1-28.

71. Schiff Berman, P. (Ed.) Understanding Global Legal Pluralism: From Local to Global, from Descriptive to Normative. In The Oxford Handbook of Global Legal Pluralism; Oxford University Press: New York, NY, USA, 2020; p. 5.

72. Napoleon, V. Thinking About Indigenous Legal Orders. In Dialogues on Human Rights and Legal Pluralism; Provost, R., Colleen, S., Eds.; Springer: Dordrecht, The Netherlands, 2013; pp. 229-245. [CrossRef]

73. Shaffer, G.; Ginsburg, T. The Empirical Turn in International Legal Scholarship. Am. J. Int. Law 2012, 106, 1-46. [CrossRef]

74. Bård-Anders Andreassen, H.-O.S.; Mclnerney-Lankford, S. (Eds.) Research Methods in Human Rights: A Handbook; Handbooks of Research Methods in Law Series; Edward Elgar Publishing: Cheltenham, UK, 2017.

75. Research Methods for International Human Rights Law: Beyond the Traditional Paradigm, Routledge Research in Human Rights Law; Gonzalez-Salzberg, D.A.; Hodson, L. (Eds.) Routledge: Abingdon, UK; New York, NY, USA, 2020.

76. Todd, Z. An Indigenous Feminist's Take On The Ontological Turn: “Ontology" Is Just Another Word For Colonialism: An Indigenous Feminist's Take on the Ontological Turn. J. Hist. Sociol. 2016, 29, 4-22. [CrossRef]

77. Garzón López, P. Pluralismo Jurídico, Derecho Indígena Y Colonialidad Jurídica. Ius Inkarri 2019, 8, $215-226$.

78. Van der Merwe, H.; Brinton Lykes, M. Racism and Transitional Justice. Int. J. Transit. Justice 2021, 14, 415-422. [CrossRef]

79. Barnor, H. Discourse on Institutional Racism: The Genealogy of a Concept. In Institutional Racism in Higher Education; Law, I., Phillips, D., Turney, L., Eds.; Trentham Books: Stoke on Trent, UK; Sterling, VA, USA, 2004; pp. 131-147.

80. Tauli-Corpuz, V. (UN Special Rapporteur for the Rights of Indigenous Peoples, Geneva, Switzerland); Viaene, L. (University Carlos III de Madrid, Madrid, Spain), Personal Interview. 7 November 2019.

81. Handbook of Action Research: The Concise Paperback Edition; Reason, P.; Bradbury, H. (Eds.) SAGE: London, UK; Thousand Oaks, CA, USA, 2006.

82. Robles Lomeli, J.D.; Rappaport, J. Imagining Latin American Social Science from the Global South: Orlando Fals Borda and Participatory Action Research. Lat. Am. Res. Rev. 2018, 53, 597. [CrossRef]

83. Berman, P.S. Understanding Global Legal Pluralism: From Local to Global, from Descriptive to Normative. In The Oxford Handbook of Global Legal Pluralism; Berman, P.S., Ed.; Oxford University Press: New York, NY, USA, 2020; p. 35. 